\title{
A new species of the millipede genus Cryptocorypha Attems, 1907, from Myanmar (Diplopoda: Polydesmida: Pyrgodesmidae)
}

\author{
Новый вид диплопод рода Cryptocorypha Attems, 1907, из \\ Мьянмы (Diplopoda: Polydesmida: Pyrgodesmidae)
}

\author{
S.I. Golovatch ${ }^{1}$, D. VandenSpiegel ${ }^{2}$ \\ С.И. Головач ${ }^{1}$, А. ВанденШпигень ${ }^{2}$
}

\begin{abstract}
${ }^{1}$ Institute for Problems of Ecology and Evolution, Russian Academy of Sciences, Leninsky prospekt 33, Moscow 119071 Russia.
${ }^{1}$ Институт проблем экологии и эволюции РАН, Ленинский проспект, 33, Москва 119071 Россия.

${ }^{2}$ Musée Royal de l’Afrique centrale, B-3080 Tervuren, Belgium.
\end{abstract}

KEY WORDS: Diplopoda, Pyrgodesmidae, Cryptocorypha, new species, Myanmar.

КЛЮЧЕВЫЕ СЛОВА: Diplopoda, Pyrgodesmidae, Cryptocorypha, новый вид, Мьянма.

ABSTRACT. A new species of the rather large, basically tropical/subtropical Asian genus Cryptocorypha is described from western Myanmar: $C$. perplexa sp.n. This is the $13^{\text {th }}$ congener, also being the first to be reported from Myanmar. It differs from all sufficiently well described species of the genus in having 20 body segments in the $\sigma^{r}$, combined with apparently the most complex gonopod structure.

РЕЗЮМЕ. С запада Мьянмы описан новый вид довольно большого, в основном тропического или субтропического азиатского рода Cryptocorypha: $C$. perplexa sp.n. Это 13-й вид в составе рода и первый, отмеченный в этой стране. Он отличается от всех достаточно подробно описанных видов рода наличием 20 сегментов тела у $\sigma^{7}$ в сочетании с, очевидно, самым сложным строением гоноподов.

\section{Introduction}

The basically pantropical family Pyrgodesmidae is amongst the largest in the class Diplopoda, at the present counting almost 400 species from nearly 180 genera alone [e.g. Hoffman, 1980; Jorgensen, Sierwald, 2010; updated]. The recently reviewed genus Cryptocorypha Attems, 1907, currently encompasses 12 species [Golovatch et al., 2011, 2013, and literature therein]: $C$. stylopus Attems, 1907 (the type species) and $C$. leia Chamberlin, 1945, both from Java, Indonesia; C. tobana Chamberlin, 1945, from Sumatra, Indonesia; C. ornata (Attems, 1938), nearly pantropical, especially characteristic of remote archipelagos; $C$. chernovi Golovatch, Geoffroy et VandenSpiegel, 2013, from Vanuatu, Melanesia, southwestern Pacific; C. hoffmani Golovatch, Semenyuk, VandenSpiegel et Anichkin, 2011, from southern Vietnam; C. areata (Carl, 1932) and C. tuberculata (Carl, 1932), both from southern India; C. kandyana (Carl, 1932), from Sri Lanka; $C$. spinicoronata (Zhang et Li, 1981), from southern China; as well as C. japonica (Miyosi, 1957) and C. kumamotensis (Murakami, 1966), from southern Honshu and Kyushu, Japan, respectively.

Because some of the species are too poorly known, no key to Cryptocorypha spp. can be attempted yet [Golovatch et al., 2011, 2013]. Thus, we still do not know even the number of body segments in the $\sigma^{7}$ of both $C$. tobana and $C$. leia. Most of the species of Cryptocorypha show 20 segments in adult $\sigma^{7} \sigma^{7}$ and oo, but in $C$. stylopus and C. chernovi the $\sigma^{7}$ has 19 segments, as opposed to 20 in the + .

The present note puts on record a new congener from Myanmar, the first to be described from that country.

\section{Material and methods}

All material was collected in 2014 in western Myanmar by Peter Jäger and Jochen Martens. The holotype and two paratypes are housed in the Museum und Forschungsinstitut Senckenberg (SMF), Frankfurt a.M., Germany, while one paratype is retained for the collection of the Zoological Museum, State University of Moscow (ZMUM), Moscow, Russia, as indicated below.

Scanning electron micrographs (SEM) were taken using a JEOL JSM-6480LV scanning electron microscope. After examination, SEM material was removed from the stub and returned to alcohol, now in SMF.

\section{Description}

\section{Cryptocorypha perplexa sp.n.} Figs 1-4.

HOLOTYPE OT (SMF), Myanmar, southern Chin State, above Kampetlet, below Mountain Oasis Resort, $1585 \mathrm{~m}$ a.s.1., N 21 $11^{\prime}$ 43.6", E $94^{\circ} 02^{\prime} 1.1^{\prime \prime}$, secondary tropical forest along stream, 10.V. 2014, leg. P. Jäger \& J. Martens. 

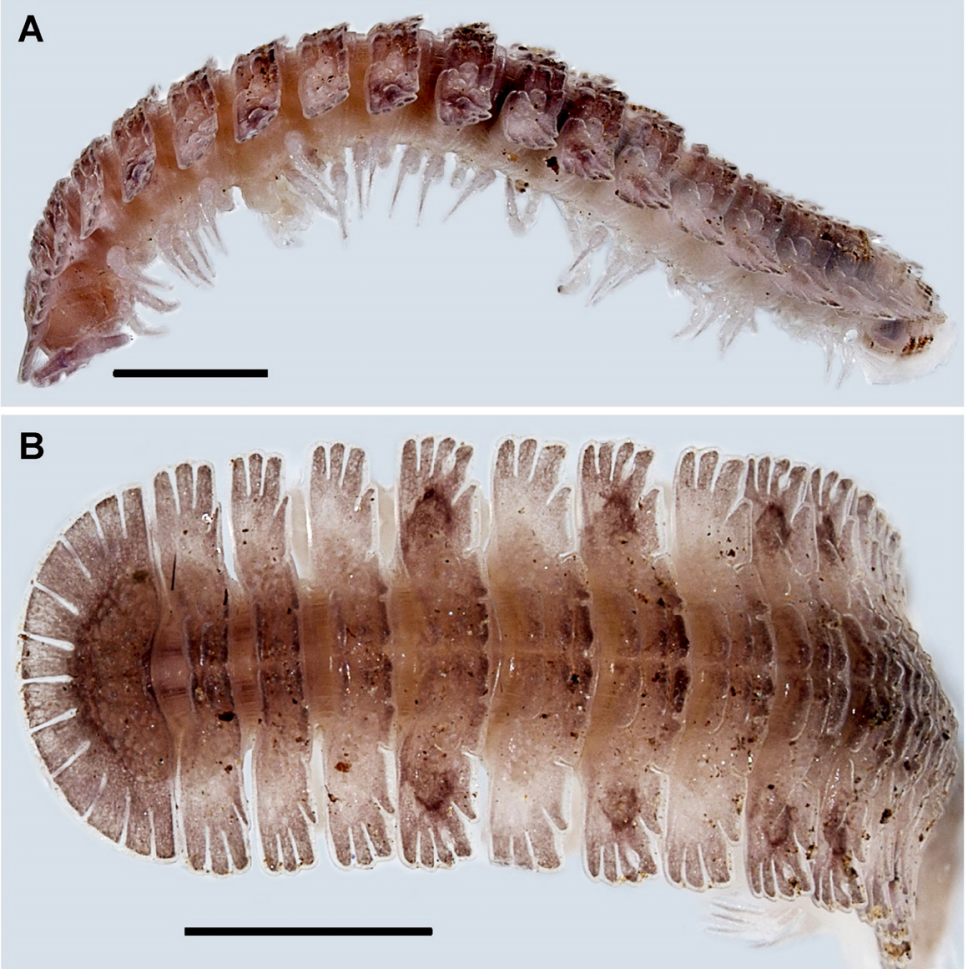

Fig. 1. Cryptocorypha perplexa sp.n., O paratype. A - habitus, lateral view; B — anterior part of body, dorsal view. Scale bars: $1.0 \mathrm{~mm}$.

Рис. 1. Cryptocorypha perplexa sp.n., паратип э. А - внешний вид, сбоку; В - передняя часть тела, сверху. Масштаб 1,0 мм.

Fig. 2. Cryptocorypha perplexa sp.n., $\sigma^{7}$ paratype. A, D, H - anterior part of body, lateral, dorsal and ventral views, respectively; B, E, I midbody segments, lateral, dorsal and ventral views, respectively; C, F, J - caudal part of body, lateral, dorsal and ventral views, respectively; $\mathrm{G}$ - crosssection of a midbody segment, caudal view; $\mathrm{K}$ poriferous midbody paratergum, dorsal view. Scale bars: $0.5(\mathrm{H}-\mathrm{J}), 0.2(\mathrm{~A}-\mathrm{G}) \& 0.05 \mathrm{~mm}(\mathrm{~K})$.

Рис. 2. Cryptocorypha perplexa sp.n., паратип О'. A, D, H - передняя часть тела, соответственно сбоку, сверху и снизу; В, Е, I - среднетуловищные сегменты, соответственно сбоку, сверху и снизу; С, F, J - задняя часть тела, соответственно сбоку, сверху и снизу; К - несущий озопору среднетуловищный паратергит, сверху. Масштаб: 0,5 (H-J), 0,2 (A-G) и 0,05 мм (K).
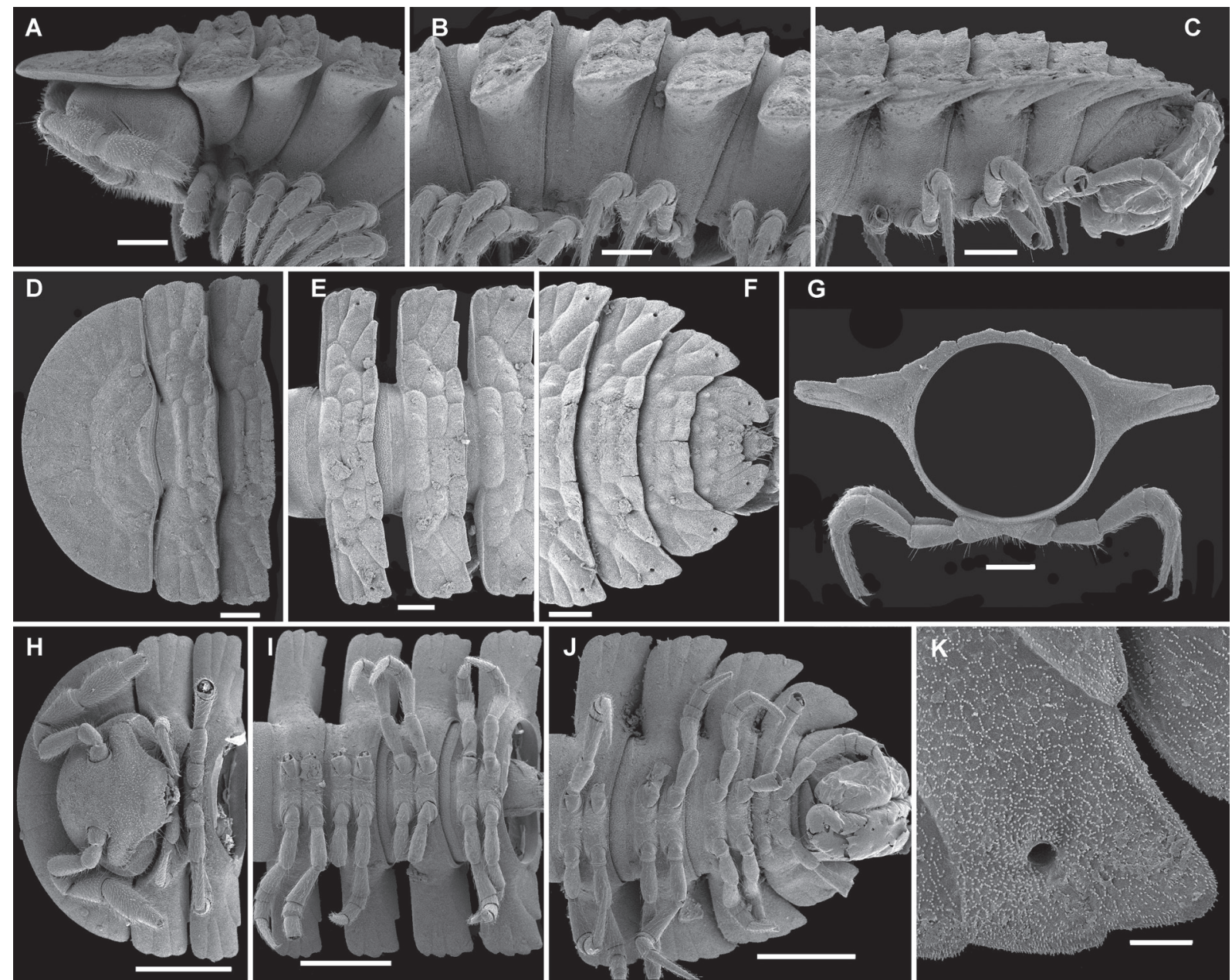

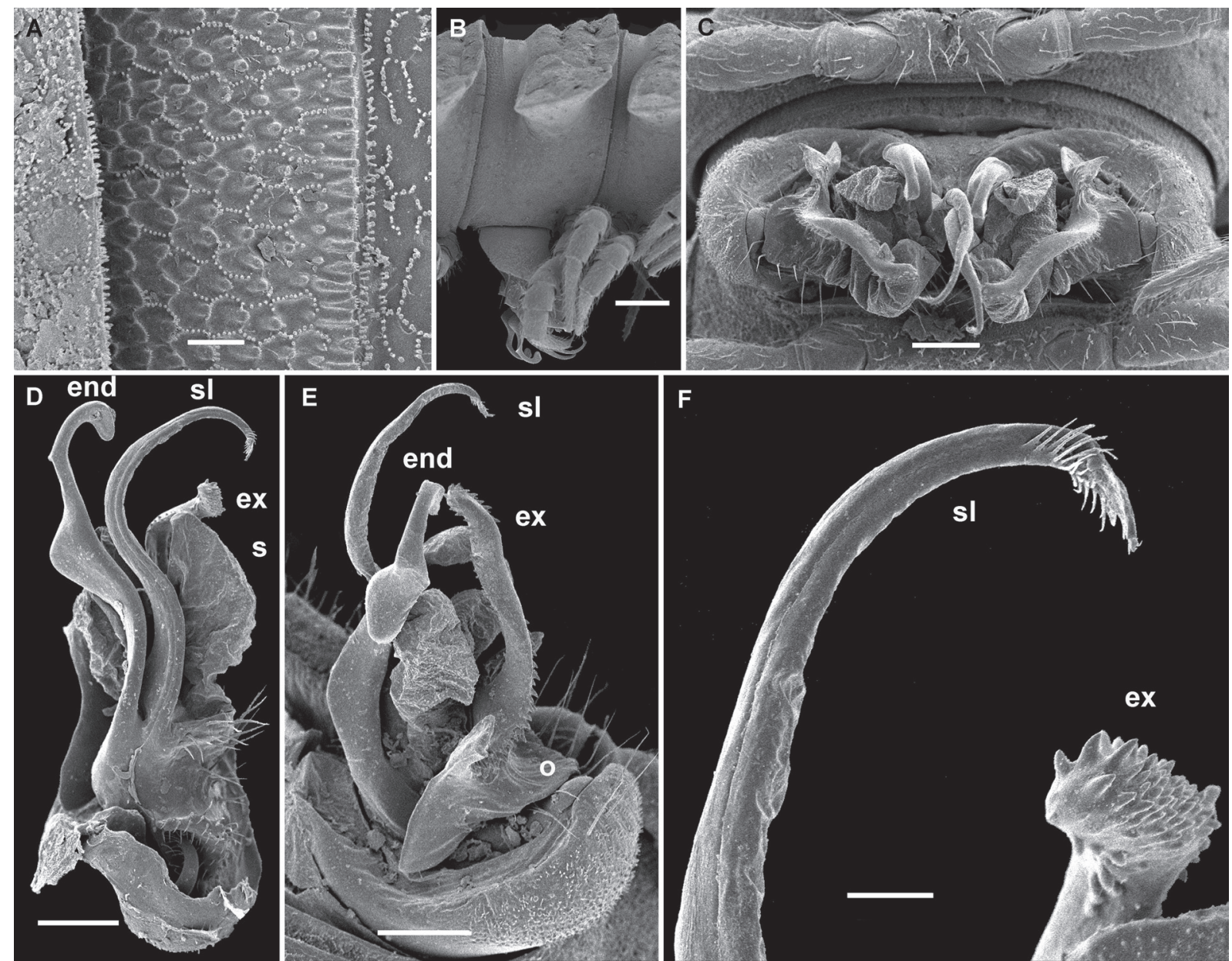

Fig. 3. Cryptocorypha perplexa sp.n., O' paratype. A — tegument texture (from left to right, limbus, pro- and metatergum); B, C segment 7 with gonopods in situ, lateral and ventral views, respectively; D — right gonopod, mesal view; E — left gonopod, lateral view; F - tip of right gonopod, mesal view. Scale bars: 0.2 (B), 0.1 (C-E) \& $0.02 \mathrm{~mm}(\mathrm{~A}, \mathrm{~F})$. Designations in text.

Pис. 3. Cryptocorypha perplexa sp.n., паратип O'. А - текстура тегумента (слева направо лимбус, про- и метатергит); В, С сегмент 7, соответственно сбоку и снизу; D - правый гонопод, изнутри; Е - левый гонопод, сбоку; $\mathrm{F}$ - вершина правого гонопода, изнутри. Масштаб: 0,2 (B), 0,1 (C-E) и 0,02 мм (A, F). Обозначения в тексте.

PARATYPES: $1 \sigma^{7}$ (SEM), 1 subadult + (19 segments) (SMF), $1 \mathrm{O}^{\top}$ (ZMUM 22563), same data, together with holotype.

NAME. To emphasize perhaps the most complex gonopod structure observed among the Cryptocorypha species.

DIAGNOSIS. Differs from all sufficiently well documented congeners by the presence of 20 body segments in the $\sigma^{7}$, coupled with a well-developed dorsal, distotibial, setigerous stump on the last $\sigma^{7}$ legs and, especially, obviously the most complex gonopod structure observed among the known Cryptocorypha species.

DESCRIPTION. Length ca 10 ( $\sigma^{7}$ paratypes) or $11.0 \mathrm{~mm}$ (holotype), width of midbody segments 1.0 and $1.9 \mathrm{~mm}$ ( $\sigma^{7}$ paratypes) or 1.1 and $2.0 \mathrm{~mm}$ (holotype) on pro- and metazonae, respectively. Coloration in alcohol from light brown to nearly pallid (Fig. 1).

Body with 20 segments, paraterga very broad (Figs $1,2 \mathrm{~A}-\mathrm{J})$. In width, head $<<$ collum $<$ segment $3=4<2<$ $5=14$, thereafter body tapering towards telson (Fig. $2 \mathrm{~F}, \mathrm{~J})$. Head subovoid, slightly transverse, densely set- ose in clypeolabral region, smooth also above antennal sockets. Interantennal isthmus nearly twice as large as diameter of antennal socket or length of antennomere 1. In length, antennomere $1<2=4<7<<3=5<6$; antennomere 6 largest, $5^{\text {th }}$ and $6^{\text {th }}$ each with a loose group of apicodorsal sensilla (Fig. 2A, H).

Collum flabellate (Figs 1, 2A, D, H), completely covering head from above; fore margin regularly rounded, with $6+6$ equal, evident, only very faintly incised lobulations, but with very long radii; middle and caudal parts with three transverse, arched, rather faint rows of low bosses, each of these surmounted by a minute knob (= insertion point of an abraded seta). Paraterga set at about upper 1/3 (O) to 1/2 ( + ) of body height, largely subhorizontal $\left(\mathrm{O}^{\top}\right)$ (Figs $1 \mathrm{~A}, 2 \mathrm{~A}-\mathrm{C}, \mathrm{G}$, $3 \mathrm{~B})$ to moderately sloping down ( $(+)$. Tegument encrusted with a microspiculate cerategument, dull, beset with microvilli arranged in a polygonal alveolate pattern (Figs 2K, 3A). Prozonae and stricture between pro- and metazonae very delicately alveolate (Figs $2 \mathrm{E}$, 

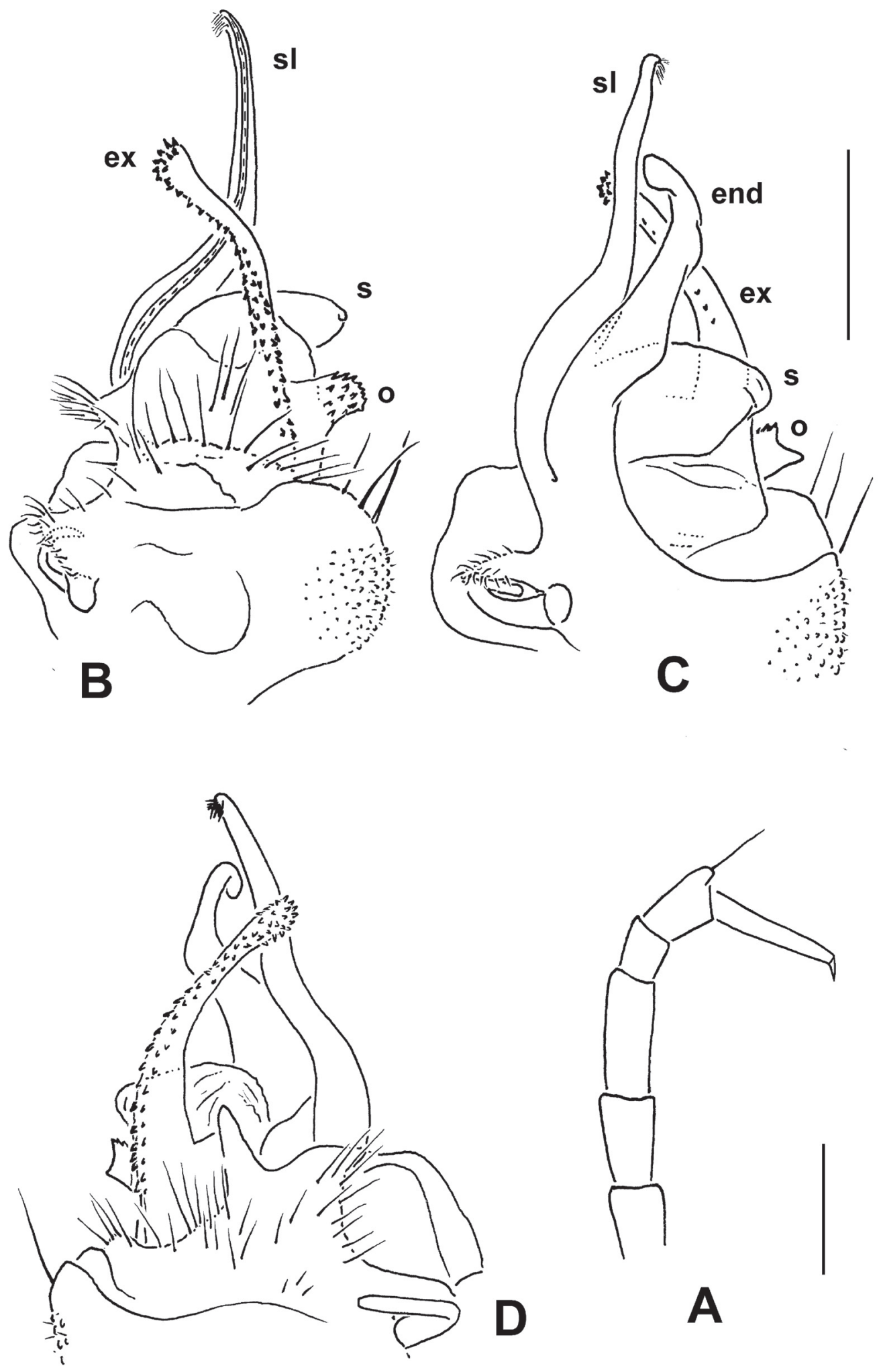

A

Fig. 4. Cryptocorypha perplexa sp.n., $0^{7}$ paratype. A - last leg, lateral view; B — right gonopod, lateral view (endomere branch broken off); C, D - left gonopod, mesal and lateral views, respectively. Scale bars: $0.2 \mathrm{~mm}$. Designations in text.

Рис. 4. Cryptocorypha perplexa sp.n., паратип O'. А - последняя нога, сбоку; В - правый гонопод, сбоку (эндомер ветви обломан); C, D - левый гонопод, соответственно изнутри и сбоку. Масштаб 0,2 мм. Обозначения в тексте. 
3A, B). Metaterga with non-differentiated tuberculations, like much of collum with three transverse and distinct rows of usually transversely oblong, polygonal to rounded, low bosses, each of these often also surmounted by a minute knob (Figs 1, 2A-G). Tergal setae largely abraded, retained ones inconspicuous, very short. Postcollum paraterga thin and rather indistinctly lobulated laterally (Figs 1, 2A-F, H-K, 3B), with three lobulations in all poreless segments, with four lobulations in all pore-bearing ones, all also delimited by very long radii both dorsally and ventrally; anterior marginals absent, but two caudal marginals evident. Pore formula normal: 5, 7, 9, 10, 12, 13, 1519 , all ozopores being very small, round, discernible dorsally at base of $3^{\text {rd }}$ lobulation (Fig. 2D-F). Limbus microspiculate (Fig. 3A). Epiproct readily visible from above, not hidden under segment 19 (Figs 2F). Hypoproct subtriangular, caudal edge with $1+1$ strong, widely separated setae on knobs (Fig. 2J). Sterna rather wide, about as broad as coxa. Legs (Fig. 2L) rather short, but slender, slightly enlarged in both sexes, tarsi longest, last tibia in adult $\sigma^{7}$ with an evident, setigerous, distodorsal tubercle (Figs 2J, 4A).

Gonopods (Figs 3C-F, 4B-D) taking up most of ventral surface of segment 7 , almost reaching bases of paraterga from below. Coxae voluminous, but rather low, transverse, each with 2-3 strong setae, microgranulate and microsetose on lateral surface; cannulae as usual; gonocoel modest, leaving most of telopodites exposed; telopodites extremely complex, directed mesad, partly crossing each other medially. Each telopodite represented by a very stout, strongly setose, prefemoral part which is much shorter than a pentapartite acro- podite. Solenomere (sl) mesal, longest, slender, rather simple, moderately curved forward, with a group of fine, short, setiform filaments at tip, branching off parabasally from both a prominent, membranous, central, sac-shaped structure (s) and an only slightly shorter, also slender and modestly curved endomere branch (end). Exomere (ex) a lateral, strong, slender, suberect branch about as high as end, beset with tiny, but strong spinicles nearly all over and carrying a short, bifid, stump-shaped outgrowth (o) caudally at base. Seminal groove terminating apically on sl.

ACKNOWLEDGEMENTS. We are most grateful to both Peter Jäger (SMF) and Jochen Martens (Mainz University, Germany) for having rendered us their material for study.

\section{References}

Golovatch S.I., Geoffroy J.-J., VandenSpiegel D. 2013. A new species of the millipede genus Cryptocorypha Attems, 1907, from Vanuatu, Melanesia, southwestern Pacific (Diplopoda: Polydesmida: Pyrgodesmidae) // Arthropoda Selecta. Vol.22. No.4. P.333-337.

Golovatch S.I., Semenyuk I.I., VandenSpiegel D., Anichkin A.E. 2011. Three new species of the millipede family Pyrgodesmidae from Nam Cat Tien National Park, southern Vietnam (Diplopoda: Polydesmida) // Arthropoda Selecta. Vol.20. No.1. P.1-9.

Hoffman R.L. 1980. Classification of the Diplopoda. Genève: Muséum d'histoire naturelle. 237 pp. (for 1979)

Jorgensen M.C., Sierwald P. 2010. Review of the Caribbean pyrgodesmid genus Docodesmus Cook with notes on potentially related genera (Diplopoda, Polydesmida, Pyrgodesmidae) // International Journal of Myriapodology. Vol.3. P.25-50.

Responsible editor K.G. Mikhailov 